\title{
Dialysis therapy, 2018 year in review \\ 8. 心血管領域一血液透析患者と脳血流障害一
}

\author{
藤㟝 毅一郎 ${ }^{1}$ 常 喜 信彦 ${ }^{2}$ 新田 孝 作 $^{3}$ \\ ${ }^{1}$ 飯塚病院腎藏内科 \\ 2東邦大学医療センター大橋病院腎臓内科 \\ 3 東京女子医科大学第四内科学講座
}

日本透析医学会の統計調査 (2016 年 12 月 31 日現在) によると ${ }^{1)}, 2016$ 年の透析患者の死亡原因における脳 血管障害の割合は $6.5 \%$ であり，これは年々漸減傾向 である。この推移は脳血管障害による直接死因は減少 しているが，その発症後の activities of daily living （ADL）低下，また quality of life（QOL）の低下は一 般人口と同様に大きな問題である。 また，近年認知機 能に関する話題が取りあげられることが多く，透析患 者におけるその機序も大変注目されている。しかしな がら, 現在でも透析患者の認知機能障害の発症が多い 原因に関しては，明確となっていないのが現状であ る. また, 最近では検査・モニタリング機器の発達で 非侵襲的に脳血流を測定することが可能となってい る. 本稿では, 2018 年に報告された透析患者と脳循環
に関連する論文の一部を紹介する。

\section{I．血液透析と脳血流量}

Polinder-Bos $ら^{2)}$ は, 65 歳以上の血液透析 (hemodialysis：HD）患者 12 名（男性 7 名, 女性 5 名, 平均年 齢 75 歳）の透析前, 中, 後の血圧変動, 脳血流量の変 化を頭部 positron emission tomography-computed tomography（PET-CT）を用いて観察，検討した。 $\mathrm{HD}$ 前から比較して血圧変動は小さいにもかかわら ず, 脳血流量は低下していた（図 1)。またこの脳血流 量の低下は, 脳のどの部位に関しても同様であった (図 2)。また, Polinder-Bos ら ${ }^{3)}$ は, 頭皮装着で脳皮質 の酸素飽和度を測定できるNear-infrared spectros-
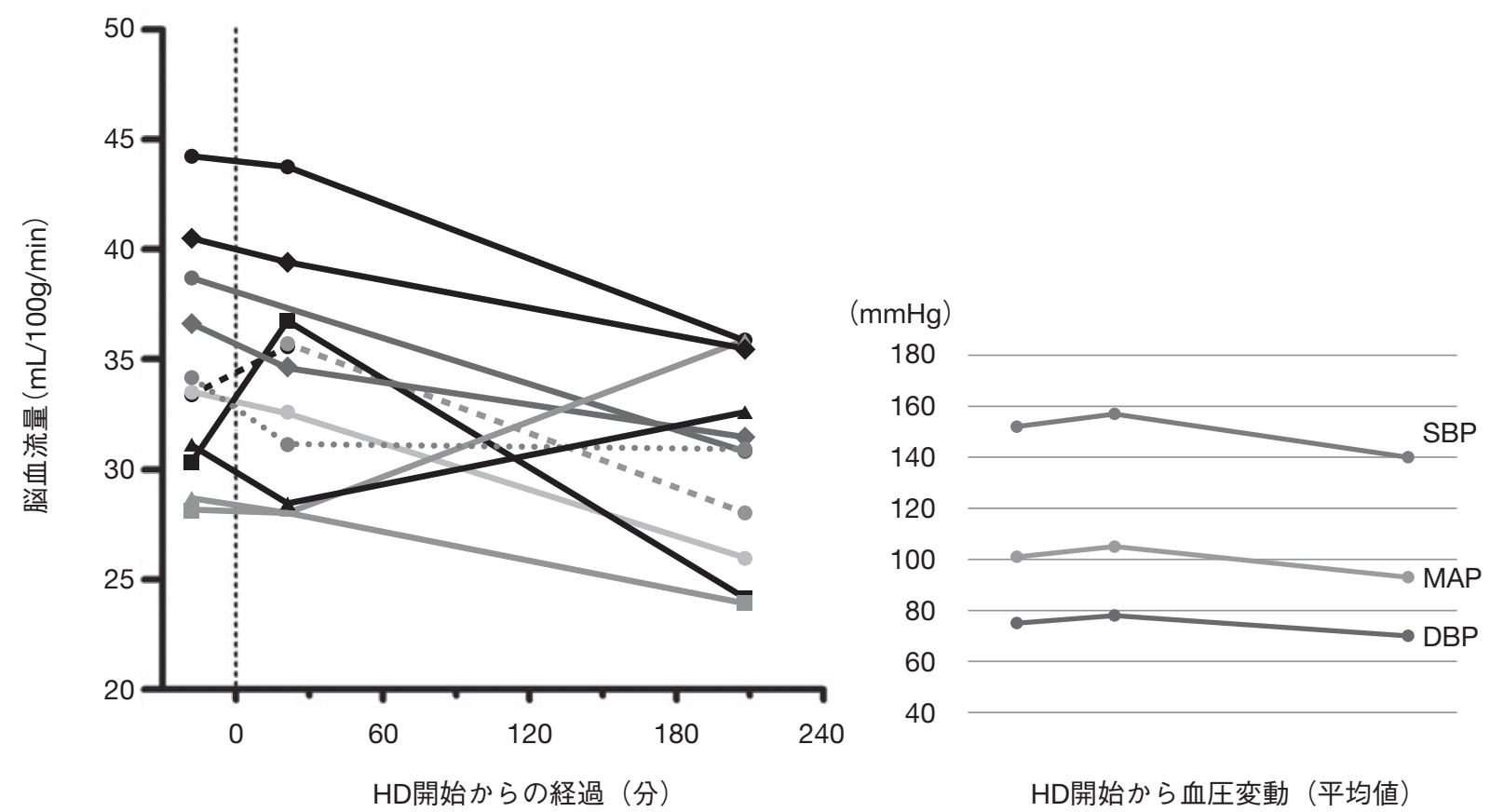

図 1 HD 中の脳血流量

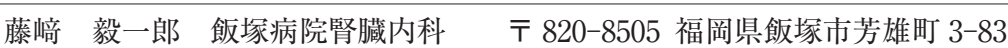

Kiichiro Fujisaki Tel：0948-22-3800 Fax：0948-29-7029 


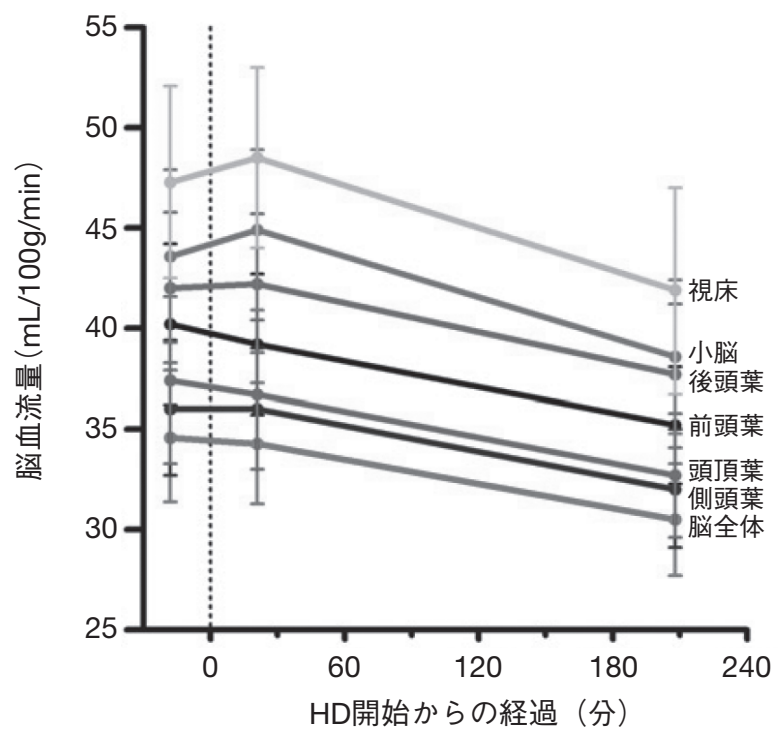

図 $2 \mathrm{HD}$ 中における脳の各部位の脳血流量

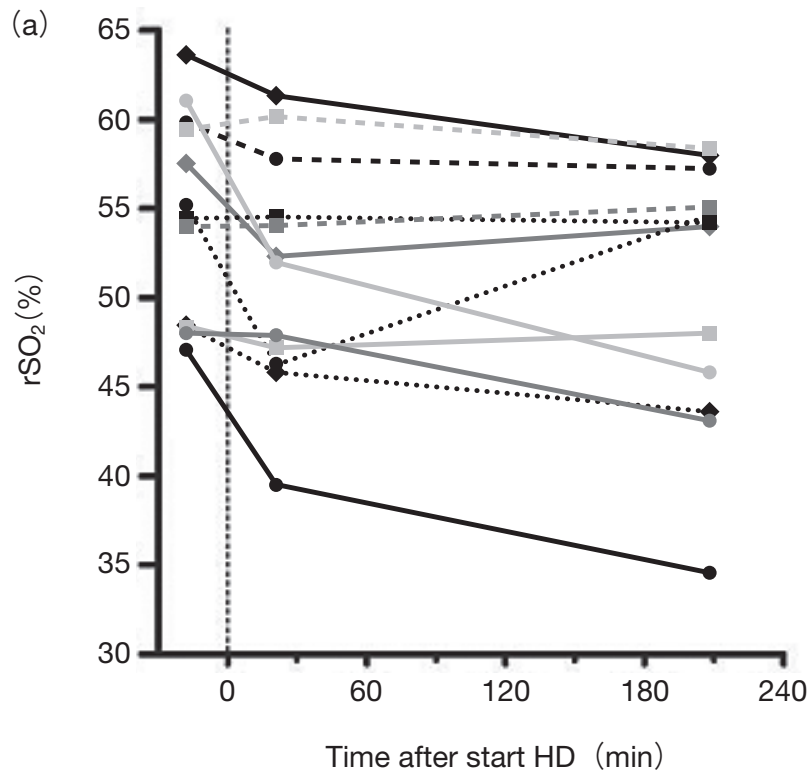

図 $3 H D$ 中の前頭葉の酸素飽和度

(a) 左大脳半球, (b) 右大脳半球

$\mathrm{rSO}_{2}$ : 脳局所酸素飽和度

copy（NIRS）を用いて前頭葉の酸素飽和度を血液透析 中に測定し, PET-CT で得られた脳血流量の変化と比 較した。 その結果, 前頭葉の酸素飽和度は左前頭葉で は低下していたが，右前頭葉は低下していなかった. 脳血流量の低下はあっても, 有意な酸素飽和度の低下 まではきたしていないことを示唆していた（図 3).

\section{II . 脳血流量と認知機能}

Findlay $ら^{4)}$ は, HD 患者 97 名 (年齢中央值 : 59 歳) を対象に前向き観察研究（1年間）を行い, 認知機能
表 1 HD 患者と腎移植患者の認知機能および脳血流量低 下の相関

\begin{tabular}{lcc}
\hline \multicolumn{1}{c}{ Assessment } & $\begin{array}{c}\text { Correlation with Percentage } \\
\text { of Decline in MFV, Rho }\end{array}$ & $P$ \\
\hline Continued HD, $\mathrm{n}=61$ & & \\
MOCA & 0.276 & 0.04 \\
TMTB & -0.403 & 0.005 \\
Transplanted at follow-up, $\mathrm{n}=12$ & & \\
MOCA & 0.086 & 0.81 \\
TMTB & -0.317 & 0.41 \\
\hline
\end{tabular}

MOCA : Montreal Cognitive Assessment

TMTB : Trail-Making test B

(b)

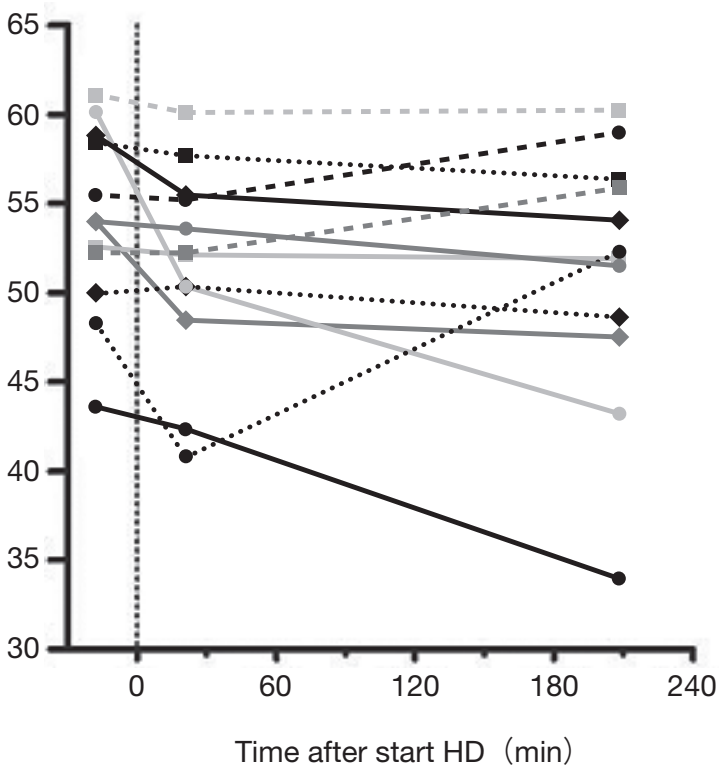

テストの結果と脳血流の関連を検討した，本研究の脳 血流量の測定は側頭骨にドップラーエコープローブを 当て, 中大脳動脈の脳血流を測定した。 その結果, 脳 血流量の低下は認知機能テスト（Montreal Cognitive Assessment, Trail-Making test B）の成績低下に有意 に相関していた（表 1)。また，興味深いことに経過中 に腎移植を受けた患者（12 名）は認知機能と脳血流量 の低下に有意な相関はなかった．本研究では頭部 MRI で検出される白質病変に関しても検討した。観察期間 中 HD を継続した患者では, 白質病変面積が増加して いたが，この増加と認知機能低下には有意な相関はな 
かった。

\section{III. 血液透析と腹膜透析}

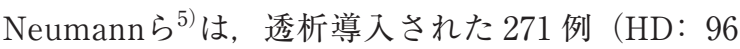
例，PD：101 例）を前向きに観察し, 導入 1 年後の認 知機能の変化を $\mathrm{HD}$ と $\mathrm{PD}$ で比較検討した. $\mathrm{PD}, \mathrm{HD}$ ともに 1 年後の認知機能は低下していたが, PD は HD と比べ認知機能の低下が有意に抑制されていた，PD はHD と比べ血行動態に与える影響が少ないが，その ことが認知機能に影響しているかは現時点では明確で ない. また，本研究は導入 1 年後の変化であり，この 変化がその後も持続するかは, 今後の検証が必要であ る。

\section{文献}

1）日本透析医学会統計調査委員会. わが国の慢性透析療 法の現況 (2016 年 12 月 31 日現在)。東京：日本透析
医学会, 2017.

2) Polinder-Bos HA, García DV, Kuipers J, et al. Hemodialysis Induces an Acute Decline in Cerebral Blood Flow in Elderly Patients. J Am Soc Nephrol 2018; 29: $1317-1325$.

3) Polinder-Bos HA, Elting JWJ, Aries MJ, et al. Changes in cerebral oxygenation and cerebral blood flow during hemodialysis-A simultaneous near-infrared spectroscopy and positron emission tomography study. J Cereb Blood Flow Metab 2018 Dec 12: $271678 X 18818652$.

4) Findlay MD, Dawson J, Dickie DA, et al. Investigating the Relationship between Cerebral Blood Flow and Cognitive Function in Hemodialysis Patients. J Am Soc Nephrol 2019; 30: 147-158.

5) Neumann D, Mau W, Wienke A, Girndt M. Peritonial dialysis is associated with better cognitive function than hemodialysis over a one-year course. Kidney Int 2018; 93: 430-438. 